Article

\title{
Eloquent Alogia: Animal Narrators in Ancient Greek Literature
}

\author{
Tom Hawkins
}

Department of Classics, The Ohio State University, Columbus, OH 43210, USA; hawkins.312@osu.edu

Academic Editor: Joela Jacobs

Received: 21 January 2017; Accepted: 27 May 2017; Published: 3 June 2017

\begin{abstract}
Classical Greek literature presents a variety of speaking animals. These are not, of course, the actual voices of animals but human projections. In a culture that aligns verbal mastery with social standing, verbal animals present a conundrum that speaks to an anxiety about human communication. I argue that the earliest examples of speaking animals, in Homer, Hesiod and Archilochus, show a fundamental connection with Golden Age tales. Later authors, such as Plutarch and Lucian, look back on such cases from a perspective that does not easily accept notions of divine causation that would permit such fanciful modes of communication. I argue that Plutarch uses a talking pig to challenge philosophical categories, and that Lucian transforms a sham-philosopher of a talking-cock to undermine the very pretense of philosophical virtue.
\end{abstract}

Keywords: animals; Achilles; Archilochus; fox; Gryllus; Hesiod; Homer; Lucian; pig; Plutarch; Pythagoras; rooster; Xanthus

\section{Introduction}

Aristotle (Politics, 1.2) and Cicero (De inventione, 1.4) both maintained that language forms one of the critical distinctions between humans and beasts (Fögen 2003, 2007). This attitude can even be felt in the Greek adjective alogon ("without logos"), which means not only "irrational" and "without language" but also (as a noun) "animal". ${ }^{1}$ Thus, as Gera and Heath have amply demonstrated, in early Greek culture verbal mastery was strongly correlated to social standing (Gera 2003; Heath 2005). Animals, since they lack altogether the capacity for language, demarcate one end of a spectrum that leads toward the masters of persuasive speech, and marginal figures like children, women, foreigners, the uneducated, and those with communicative disabilities are mapped somewhere between these extremes. Verbal animals, therefore, represent a category crisis that demands explanation (Fögen 2003, 2007), and by situating speaking animals in the wider range of classical attitudes we can hear a paradoxically eloquent alogia.

The "animal turn" in contemporary literary studies seeks to take the role of animals in literature more seriously, based, in part, on the modern realization that animal (and even plant) communication is far more complicated than had previously been realized (McDonell 2014; DeMello 2013; Plec 2013; Karban 2015; Radick 2007; Diamond 1992; Herman 2016). Yet efforts to study animal narrators constantly bump up against the limits of this project. ${ }^{2}$ Speaking animals are presented in terms of a uniquely human trait, namely human language (Wolfe 2016), and thus they are constructed via a pathetic fallacy that offers us not a window into the bestial soul but a mirror that reflects how humans

1 In the story of Epimetheus' botched distribution of animal capacities, for example, Plato says that the dim-witted Titan apportioned all available skill-sets and capabilities among the beasts ( $t a$ aloga) while forgetting to reserve any such benefit for humans (Protagoars, 321b-c).

2 See (DeMello 2013) and (Herman 2016) for creative efforts to overcome this problem. 
conceptualize (i.e., create and make knowable through our language) animals. Such an assertion need not deny or even erode the possibility of animal languages or human-non-human communication. ${ }^{3}$ I am confident that I and the dog, who keeps me company as I write this article, communicate, but as soon as I "report" his words by means of my vocabulary, grammar and personal context, I am speaking through or for him rather than hearing his voice. ${ }^{4}$

Even if the idea of hearing what animals really want to "say" must remain a fantasy, in taking literary depictions of verbal animals more seriously, we can hope to reach other goals. In the following pages I build on the work of Gera, Heath, and Fögen (Fögen 2003, 2007; Gera 2003; Heath 2005) to suggest that speaking animals from ancient Greek literature often engage with Golden Age narratives. I begin with two archaic case-studies: a horse, who speaks prophetic Homeric hexameters, and a fabular fox, whose voice provides an ethical example for human conflict. In these early examples, the animals are fully animal and their voices derive from an earlier world order that is no longer directly accessible. These animal voices thus have another-worldly authority, and their speech works differently from the limited and fallible language of humans, thereby setting up a contrast between the two systems of communication. I then turn to the later end of antiquity, where a pig and a rooster speak, but only because they used to be human. The gimmick of a talking animal may have lost its attractions by this era, since these animals speak not from another world but as overtly humanized voices that provide philosophical (pig) and satirical (rooster) commentary on their contemporary world and earlier Greek culture. ${ }^{5}$ These later examples look back to earlier models to establish animal voices as a miraculous interruption of the world order, but the supernatural gambit quickly devolves into a commentary on purely human affairs.

\section{Houyhnhnmic Prophecy}

With his divine maternal inheritance, Achilles experiences human emotions at a superhuman level. His mênis (the "rage" that drives the Iliad) is a form of divine, rather than human, anger, and his grief at the loss of his beloved Patroclus prompts a berserker's bloodlust few social codes can tolerate (Muellner 1996). Thus, as he grieves for his dead friend it is hardly surprising that he rails even against Xanthus and Balius, his horses that had conveyed Patroclus into, but not back from, battle. The surprise, rather, is that Xanthus replies to Achilles' chastisement with ten hexameter lines that refute the hero's charge that the horses were somehow negligent in Patroclus' death and predict Achilles' own imminent demise at the hands of Paris and Apollo. Homer frames the horse's words with two divine interventions: he notes that Hera had granted Xanthus the power of speech (audêeis, 19.407), and the Erinyes (Furies) then immediately check his voice (eskhethon audên, 19.418). ${ }^{6}$

These lines have long puzzled Homeric commentators, and the relevant issues are difficult to resolve. ${ }^{7}$ I follow Johnston's arguments that this scene pulls together a variety of mythical motifs that are only alluded to here (Johnston 1992). Most importantly, she reconstructs a heroic pattern of Hera giving divinely-sired speaking horses to heroes and claims that the Erinyes appear because of

3 For this general concept, see (Plec 2013); for the ancient debate about animal rationality in general, see (Sorabji 1993; Horky 2017); and on the role of talking birds in this ancient debate, see (Sorabji 1993, pp. 80-85) and (Newmeyer 2017, pp. 66-67).

4 I am grateful to the anonymous referee of this article who directed me to Arrian, Cynegeticus 5.2 as an ancient parallel for this relationship between an author and his dog.

5 Though the historical disjunction is not strict. (Spittler 2008, pp. 130-40) discusses the example of a talking dog in the Acts of Peter in relation to classical models.

6 Homer's Odyssey presents several other moments of animal communication: an eagle that represents Odysseus speaks in a dream to Penelope (19.535-50), Odysseus' dog Argus does not speak, but he lifts his head, sees through his master's disguise, and wags his tail at the sight of his long-lost friend (17.291-327), and the Cyclops Polyphemus addresses his ram (9.446-60) in a manner that may suggest that the animal had the ability to respond in the past. For the latter scene, see (Fögen 2007, pp. 67-68; Gera 2003, pp. 13-15; Heath 2005, pp. 79-84).

7 Already the ancient commentaries (scholia vetera) on Homer grappled with these lines. A note on line 407 takes the time to explain that audêeis implies "having the voice of a rational animal" ( on 418 alternately proposes that the Furies are involved here because they are "overseers of things contrary to nature"

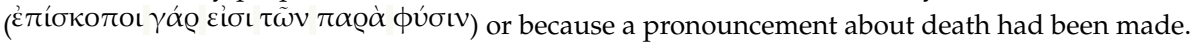


their chthonic connections with prophecy. On Johnston's reading, we should not assume that Hera has just now given Xanthus the power to speak nor that the Furies have done anything more than brought the motivation for this prophesy to an end. They do not, that is, permanently remove Xanthus' ability to converse in human language. I agree with Johnston's assessment of the details of this scene, but I add that the Erinyes' silencing of Xanthus parallels a range of details suggesting that epic bards pitched their tales as coming from a lost era that was closer to a Golden Age (Gera 2003, pp. 18-67). The Erinyes take the horse's voice, that is, not in a narrow move to deprive Xanthus of his special powers but as one of many indicators that the "there and then" is different from the "here and now". 8

Narratives about the end of a Golden Age tend to draw on a standard set of motifs, such as the separation of divinities from humans, a shortening of the human lifespan, the end of spontaneously produced agricultural bounty, the need for clothing and, most important for our project, the transformation of language. Familiar stories from Genesis make this clear. Adam and Eve must leave the Garden of Eden, where they had interacted directly with God, after an encounter with a talking serpent. Once outside this enclosed paradisiacal space and cast into the wilderness beyond, the world is governed by a different set of rules. Later in Genesis, the cataclysmic flood (a common Near Eastern motif) provides a second cultural rupture that reboots humanity and leaves us with shorter life spans. The theme of language looms most prominently in the tale of Babel, where the unified human language is divided into countless tongues in response to human transgression. ${ }^{9}$ The end of Golden Age narratives helps construct a familiar pre-modern world in which we no longer live as long as Methusela, and we wear clothes as we work the fields; animals provide us with labor and food; and whereas snakes no longer speak, humans have a wide variety of languages. Augustine even suggests that language as we now understand it is itself a consequence of our expulsion from the Garden: "The explanation for the bodily (corporaliter) uttering of all these words is the nadir of the age and the blindness of the flesh, by which thoughts cannot be seen, with the result that there is this tintinnabulation in the ears" (Confessions 13.23.34). ${ }^{10}$

Although the details can be changed, the rough opposition between then and now is replayed in Greek sources as well. The wedding of the mortal Peleus and immortal Thetis, which precipitates the entire Trojan saga, shows gods and humans feasting together as a feature of a world that is fading away in Homer's poems. ${ }^{11}$ Scodel has shown that the flood narrative has been adapted into the Homeric context through the anticipated deluge that Apollo and Poseidon will orchestrate at the end of the Trojan War to destroy the Achaean wall (Iliad 12.3-35) (Scodel 1982). Both the land of the Cyclopes and Scheria, the home of the Phaeacians, show some signs of being Golden Age spaces, at least until they interact with Odysseus. ${ }^{12}$ The same idea of a new world ordering appears in Hesiod's tale of how gods and humans gathered at Mecone and made a new settlement to facilitate communication for the coming era in which mortals and immortals no longer interact directly. This new order came about when the Titan Prometheus (the father of Deucalion, the lone male survivor of the Greek flood) demonstrated the basic sacrificial precedent for burning the well-dressed but inedible portions of an animal to the gods while reserving the seemingly humbler but more nutritive bits for human consumption. Human existence is now framed in terms of our estrangement from the gods and

8 This is not to say, however, that I agree with those who interpret the Erinyes as guardians of the natural order (e.g., (Edwards 1991, p. 285)). There is some evidence for this position in the scholium (ancient commentary) to line 19.418, but that is hardly convincing whereas Johnston's counterarguments are.

9 Herodotus (2.2-5) preserves a tale about the Egyptian Pharaoh Psammetichus conducting an experiment to discover the original and natural language of humans. Based on the first word uttered by an infant raised in isolation, the Pharaoh concluded that Phrygian is the original human language.

10 All translations are my own.

11 Descriptions of the wedding are preserved at Kypria fr. 3 Davies $1988=$ fr. 3 Bernabé 1987, Pindar Pythian 3.86-96, Nemian 4.65-68, 5.22-39, Isthmian 8.46-47, and on the Francois Vase.

12 Both areas are notably fecund and their inhabitants have easier interactions with some divinities, yet both have non-Golden Age traits as well (Vidal-Naquet 1998, pp. 26-27) on Scheria as both an ideal and a typical Greek settlement; (Gera 2003, p. 15) on the land of the Cyclopes as a "halfway golden age world"; see also Plutarch, Gryllus, 986F. 
our domination over animals, who come to serve as our food and a means for contacting the gods. The clearest proof that Hesiod was thinking in terms of epochal distinctions appears in his account of the five ages, in which the Golden Age fades to Silver, then Bronze before an age of heroes intervenes, and we find ourselves (with Hesiod) in the sad age of Iron (Works and Days, 109-201). The heroes who became the subject of Homeric poetry thus inhabit a story world that precedes our current degraded age, but they too are separated from the earliest and best eras. What all these stories have in common is that they present a different system of being in the world, in contrast to which the current era must develop indirect and imperfect means for communicating with the divine realm through such structures as sacrifice and prayer.

In classical sources, we hear more about the movement from loquacious humans into the animal realm (most famously in Ovid's Metamorphoses), but a few writers preserve the idea of a primordial world in which animals could speak. Callimachus, working in Alexandria in the third-century BCE, offers one example of this in the second poem of his now fragmentary collection of Iambi (Acosta-Hughes 2002, pp. 152-90; Steiner 2010). The poem centers in an Aesopic tale about an era when animals could talk, and a swan asked the gods for a release from aging. ${ }^{13}$ The request seems to have been turned down, because a fox accuses Zeus of ruling unjustly (without dikê). In response to this increasingly unruly cacophony of voices, the father of gods and men decides to silence the animals and transfer their voices to humans. There follows a list of jokes that modern readers are not well positioned to assess, but the basic logic is simple enough: the story explains why so-and-so now speaks like a dog, someone else like a donkey, etc. Years later, Callimachus' fellow Alexandrian, Philo (c. 25 BCE-50 CE) told a similar tale, surely inspired, as Acosta-Hughes has shown, by Callimachus' poem (Acosta-Hughes 2002, pp. 175-82). In commenting on the Biblical story of Babel, Philo relays a tale about a time when animals shared a common language (De confusione linguarum 6-8). This ability to communicate leads to a network of shared values and sympathies, and eventually they raise a collective voice demanding immortality for themselves. Predictably, the animals are punished by having their shared language splintered. The unified political force of the animals is neutered when their ability to share their thoughts and feelings is taken away, and the Golden Age concludes by leaving the world with voiceless and brutish animals that have no claim to justice. Finally, the fable writer Babrius (probably working in Cilicia in the first or second century CE) looks back to a bygone era when animals could speak. His first prologue sets up this division between then and now by positing three ages (Gold, Silver and Iron) and then positioning Aesop as the unique intermediary whose knowledge of the animal world permits him to transmit that lore to us (Prologue 1.5-16, Perry):

$\dot{\varepsilon} \pi \grave{i} \tau \tilde{\eta} \varsigma \delta \dot{\varepsilon} \chi \varrho v \sigma \tilde{\eta} \varsigma \kappa \alpha \grave{\imath} \tau \dot{\alpha} \lambda$ oเ $\pi \dot{\alpha} \tau \tilde{\omega} \nu \zeta \omega \omega \nu$

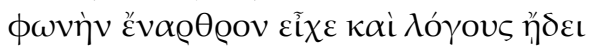

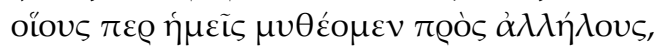

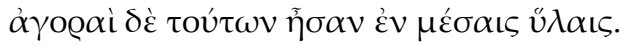

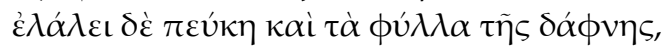

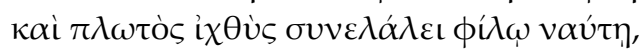

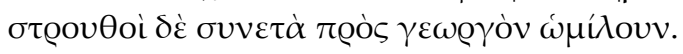

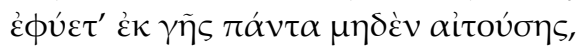

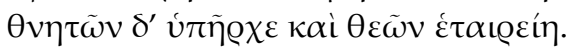

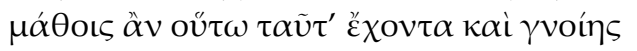

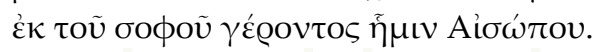

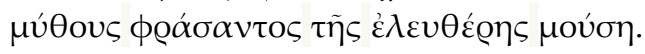

Now, in the Golden age the other creatures, too, had intelligible voices and used words such as we ourselves do in telling each other tales, and their gatherings were among the trees. Even the Pine and the leaves of the Laurel talked, the Fish as it swam chatted with

13 Speaking animals are, of course, a commonplace of ancient fables. See (Fögen 2007, pp. 67-68) and (Gera 2003, pp. 207-12). 
the friendly sailor, and the Sparrows conversed intelligibly with the Farmer. Everything grew from the untilled earth, and among mortals and gods good fellowship prevailed. That this was so, you may learn and fully understand from wise old Aesop, who has told us fables with his free Muse.

The wisdom of fables, that is, comes to us from a different era of discourse, and whereas Homer and Hesiod claim to access privileged information via the inspiration of the divine Muses, Callimachus and Babrius set up Aesop as the historical intermediary node of communication. Callimachus, Philo and Babrius provide an outline for understanding the end of the Golden Age in terms of a transformation of language that explains why communication-among humans but also between the realms of animals, humans and gods-is so difficult. The fantasy of a time when such communication was simpler and more straightforward speaks to a deep human anxiety about limitations of language.

To return to the case of Xanthus, as the Erinyes silence the speaking horse, we can recognize one more epoch-ending moment. On this reading, it makes perfect sense that the horse speaks in an oracular mode. A speaking animal in this context does not replace human voices (as, for example, the mock-epic Battle of Mice and Frogs, which substitutes animals for Homeric characters), rather it gives the impression of a Golden Age moment of communication. The voice is, therefore, not uniquely equine either, since the information Xanthus gives could have been provided just as well by a passing eagle or come through the medium of a human prophet, a divine epiphany or an animal sacrifice. ${ }^{14}$ The layering of temporal frames within which Xanthus' lines ring forth makes this particularly poignant, as the greatest figure of the heroic age hears a last Golden Age communication. Achilles learns that his own demise draws near, while we realize that we stand at a double separation from such clarity of communication and understanding. Animals no longer speak, and Xanthus' unexpected Homeric eloquence derives not from his horseness or his animality but, rather, from the entire complex of Golden Age idealizations against which the human condition is framed.

\section{What Does the Fox Say?}

Whereas Homer and Hesiod emerge from a panhellenic story-telling tradition in contact with the Near East, Archilochus, remembered as the seventh-century BCE "inventor" of iambic (and sometimes also elegiac) poetry, speaks with a voice localized in the Aegean islands (especially Paros and Thasos). Archilochean iambos conjures a strikingly un-heroic world that contrasts sharply with the beauty and nobility of Homer. The scurrility for which he was later reviled, however, seems not to have been out of place in the archaic and classical eras. Indeed he was frequently remembered as one of the preeminent early poets ("second only to Homer"), which makes it all the more lamentable that his corpus survives today in a hodge-podge of papyrus scraps and quotations by later authors. ${ }^{15}$ Legends about his life coalesce around a scenario in which an older Parian named Lycambes had promised to give his daughter Neobule to him in marriage. When Lycambes reneged, Archilochus retaliated with such a vicious barrage of poetry that Lycambes and his daughters hanged themselves in shame. Whatever kernel of truth may lie beneath the accreted layers of elaboration, this story provides an ideal etiology for one aspect of archaic Greek iambos, namely its power to launch blistering verbal attacks upon a personal enemy. A prominent feature of Archilochean invective is the incorporation of fables (not yet associated with Aesop at this early date) in which animals speak, and these voices offer a starkly different kind of eloquent alogia.

14 This is not to say that the role of the horse is irrelevant here. Horses have close connections with heroes, making the former an apt choice for communicating with the latter. The Greek fabular economy of animal types was rich and complex, but that is a matter of medium. In this case, the aptly chosen medium of the horse delivers a message that is not, in itself, in any way equine.

15 Dio Chrysostom (Orations 33.11-12) is the most overt in putting Archilochus on par with Homer. For a detailed assessment of the ancient pairing of the two poets, see (Lavigne 2016). 
The poem that has most plausibly been connected to the rupture between Archilochus and Lycambes begins by setting the conflict in front of the Parian community (fr. 172 West):

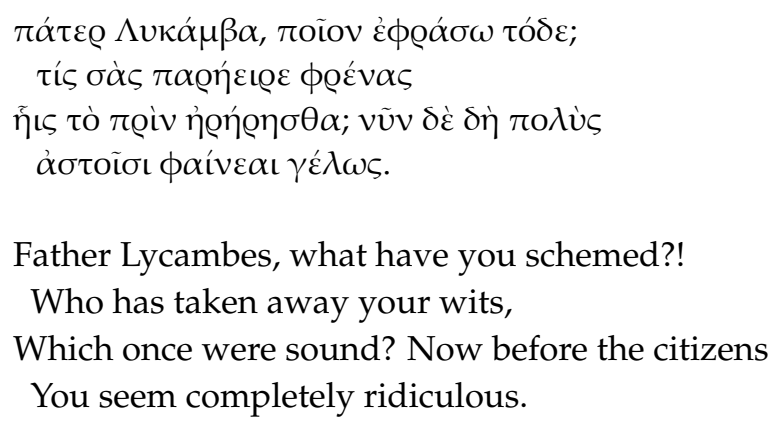

Very little is certain about the reconstruction of this poem, but it seems to go on to mention a broken oath (fr. 173 West) before introducing a fable (ainos, cognate with ainigma or "riddle") about a fox and an eagle, who struck up a friendship (fr. 174 West). This fable later became associated with Aesop and was widely known throughout antiquity, but presumably Archilochus' version was not exactly the same as those later retellings. Nonetheless, the bits of this poem that survive accord with the basic plot that the eagle broke faith with the fox, snatched up its kits, and gave them as a meal to her eaglets (fr. 175 speaks of "bringing an unlovely meal to unfledged children" who seem to be in a nest). As the fox curses its fate, the eaglets somehow fall to the ground where they are gobbled up by the bereft fox.

Most commentators associate details of the legend of the broken marriage agreement with specific themes in the fable (Steiner 2010; Irwin 1998; Hawkins 2008) "Father" Lycambes, the older, loftier, figure stands for the eagle, since both turn their backs on a pre-established plan. Archilochus plays the part of the fox (which he does in other poems), who is jilted but ultimately finds a path to revenge. And the whole animal narrative hinges on the role of children, the expected goal and outcome of any marriage in ancient Greek culture. By going back on his promise to marry his daughter to Archilochus and thereby depriving the poet of future offspring, Lycambes acts like the eagle.

Within this framework, we find two moments when the fox speaks. First, in fr. 176 West, most readers agree that the fox, already mourning the loss of its kits, says to itself:

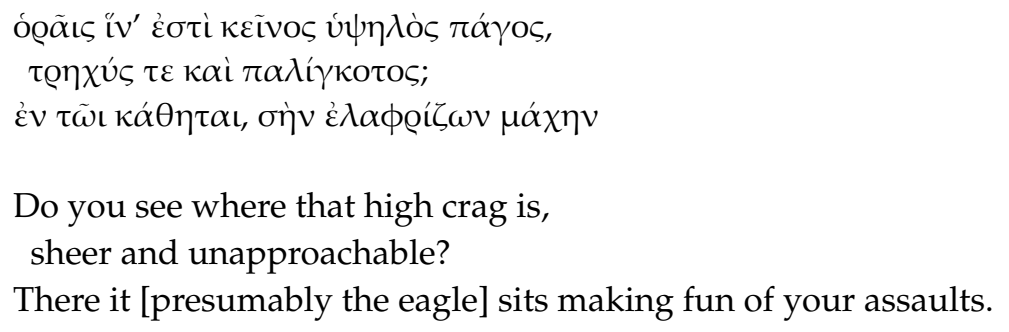

Nothing that the fox can do-accusing, cursing, grieving, pleading-influences the eagle, safe at its inaccessible elevation, just as Lycambes remains safe from the complaints of Archilochus. It may be that as the fox recognizes the ineffectiveness of such approaches, she comes up with a more powerful strategy. Fr. 177 West (again, assumed to be spoken by the fox) is a prayer to Zeus:

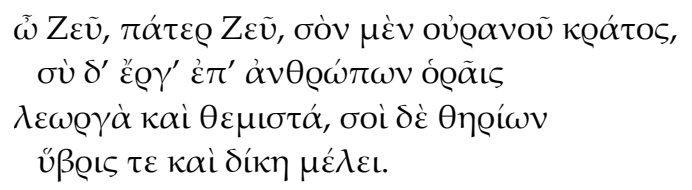

O Zeus, father Zeus, you who wield heaven's power,

You look upon the affairs of humans,

Both reckless and lawful, and the beasts'

Transgressions and justice are your concern. 
These lines stake three claims, when we focus on the role of the speaking animal. First, Archilochus here reverses a point made by Hesiod in Works and Days, which claims that Zeus gave justice (dikê) to humans but not to "fish, beasts and winged birds" (276-80), who eat one another as part of the natural order. ${ }^{16}$ Earlier in that same poem, Hesiod had told a fable about a hawk and a nightingale, and that inset tale, directed specifically to "kings who understand" (202), suggested that might makes right both among animals and humans. With his later comment about the uniquely human relevance of justice, however, he shows the limitations of thinking of animals as models for people. As a symbol, the hawk appears in the poem as a representative of human rapacity, but as a bird, its domination of the nightingale has no ethical valence whatsoever, since matters of justice are absent from the animal realm. Animals are incorporated into a human ethical discourse only to be excluded as animals from ethical concerns or included only inasmuch as they offer a taxonomy of human types.

Second, by reversing Hesiod's separation of humans and animals in terms of justice, Archilochus makes a strikingly different move-one that encourages fantasies about how animals might have been conceptualized differently had Archilochus, rather than Hesiod, emerged as the canonical poet. Archilochus' (fox's) presentation of a Zeus concerned for animal justice allows us to return to the relationship between his poem's framing narrative (about Lycambes and, presumably, the ruptured marriage pact) and the inset fable. As Payne has already noted, the fox's claim establishes a sympathetic continuity between human and animal (Payne 2010, p. 35). Archilochus' anger at Lycambes exists on the same spectrum as the fox's anger at the treacherous eagle, and this encourages us to evaluate the human and animal scenarios on similar terms. If it is natural and unobjectionable for the fox to eat the eagle's offspring, then such a response should be acceptable in Archilochus' reaction to Lycambes. The story that Lycambes and his family committed suicide thus balances the conclusion of the fable. Whereas Hesiod's denial of justice to animals makes the hawk's treatment of the nightingale ethically different from an unequal power dynamic among humans, Archilochus creates a scenario in which human justice can be informed by non-human behavior. The fox's eating of the eaglets becomes both ethically justified and driven by an impassioned need for revenge.

If Archilochus' fable elides the differences between him and the fox, we find two apt comparisons in Trojan War mythology. Near the end of the Iliad, as Achilles and Hector face off, the latter suggests a plan that the eventual victor should respect the corpse of the defeated enemy. To this Achilles responds that there can be no such agreements between lions and humans or between wolves and sheep (22.261-67). Moments later Hector lies dying, and he begs Achilles to grant him proper burial. Achilles wishes that "my fury (menos) and spirit (thumos) could prompt me to chop you up and eat your flesh raw" (346-47), and he predicts that Hector's corpse will be devoured by dogs and birds (335-36 and 348). We hear no speaking animals in this scene, but we find the limits of Achilles' rage, since he cannot quite become animal to actually ingest his enemy, a job he leaves to scavenging birds and dogs who will eat Hector's flesh but without Achilles' animus. Later, in an episode not preserved in Homer but related in Euripides' Hecuba, Hector's mother, Hecuba, reaches her breaking point after the fall of Troy as she is forced to face horror upon horror enacted upon her children. When she hears that her youngest son Polydorus has been killed by a former ally, she takes vengeance on her enemy's children. In the outcome, the ghost of her son tells her that she will be transformed into a $\operatorname{dog}(1265)$ and her final resting place will be known as "Bitch's Tomb" (1271-73). Franco has shown how this fate represents a fitting emblem of Hecuba's relentless focus on defending her children, a trait closely associated with a maternal canine instinct in early Greek literature (Franco 2014, pp. 108-18). ${ }^{17}$

16 As noted by Corrêa (Da Cunha Corrêa 2007, pp. 112-13). For the fullest treatment of animals in Archilochus, see (Da Cunha Corrêa 2010).

17 Gregory emphasizes the darker side of this association when she notes that "Hecuba has become morally indistinguishable from the dog whose shape she is destined to assume" (Gregory 1999, p. xxxiii). For an excellent treatment of Hecuba's revenge narrative, as well as a succinct overview of the history of scholarship on this topic dating back to the Renaissance, see (Mossman 1995, pp. 164-203). 
Whereas Achilles cannot quite cross into an animal savagery, Hecuba behaves like "a bitch protecting her pups" (Semonides, fr. 7.34-36 West), and this brings her to the point of being something other than human, what Kovacs has described as an "extraordinary force, at once sub-human and super-human, bestial and divine" (Kovacs 1987, p. 109). ${ }^{18}$ Archilochus uses his animal fable and the words of the fox to do something similar: within his poem he assimilates his lust for revenge to that of the fox and thereby normalizes his murderous intent via the just practices of animals as authorized by Zeus. At the conclusion of the fable we return to the world of human voices, but the speaking fox demonstrates that human passion is both regulated by the dictates of justice while also being extended and normalized through the example of the animals' conflict.

As a final comment on the fox's voice, we can return to the comparison between animal voices and sacrifice. Hesiod's Prometheus shows that sacrifice was established at the moment when gods and humans ceased to eat together, the moment, that is, when face-to-face communication ended. A new social order goes hand-in-hand with a new approach to food and animals, and sacrifice becomes an imperfect substitute for direct communication between humans and divinities. At a moment of crisis and despair, the Archilochean fox prays, and his prayer (another postlapsarian stop-gap) is answered. Later versions of the fable, such as Aesopica 1 (Perry 1952) and the Latin version of Phaedrus (1.28), say that the eagle snatched a bit of smoldering sacrificial meat from an altar and that this hot morsel set the birds' nest ablaze, causing the unfledged eaglets to fall to the ground, where the fox gobbled them up. Although the surviving Archilochean fragments are so incomplete that we cannot be certain of all the details, several words suggest that this basic pattern was to be found in his poem as well. The fox's ability to speak derives from a Golden Age past, but whereas Xanthus speaks with divine authority and inspiration, the fox serves as an idealized model of life beyond the Golden Age. The fox's prayer works, since it leads directly to a violation of sacrificial practice (food on an altar is for the gods) and divinely sanctioned retribution. The fabular animal's voice can do what human prayer intends, namely to convey mortal concerns directly to the divine realm and to prompt a direct response. Prayer does not always work that way for humans, and thus the fox's voice (like that of Achilles' horse) suggests the fantasy of a world in which contact with the divine is direct and efficacious. This pattern inside Archilochus' poem parallels the legendary efficacy of his poetry in human society as attested by the legendary suicide of the Lycambids.

\section{Happy as Pig in Mud}

We now jump nearly a thousand years from Archilochus' archaic milieu to a time when Rome exerts stable control over Greece and imperial trade routes foster communication across a huge swath of cultures. Earlier examples could, of course, be adduced, but by sampling cases of talking animals from the early and late extremities of the classical Greek world, we can find a broad vista of attitudes and approaches to this narrative device. As we will see, furthermore, imperial Greek authors frequently returned to material drawn from much earlier eras. One such example comes from Plutarch (c. 46-120), the prolific Boeotian biographer, essayist, civil servant and Middle Platonist philosopher. Within his collection of shorter works known as the Moralia, we find a brief, and probably fragmentary, dialogue typically known as Gryllus, also titled "On the Fact that Unreasoning Creatures Use Reason". This longer title plays on the oxymoron that animals (ta aloga, "the things lacking logos") by etymological definition lack logos, which means both "reason" and "voice", even though the text presents a speaking pig arguing on behalf of its own intelligence. As often with humorous texts, how we assess that pun will frame what we take away from this essay, which can be understood as anything from pure frivolity to a serious case for animal intelligence in stark contrast to Stoic thinking.

18 Franco speaks of Hecuba's "uncontrollable wrath", which calls to mind Achilles' ferocious return to battle after the death of Patroclus (Franco 2014, p. 110). Hecuba's delimitation of human boundaries participates in a network of themes that Ringer studies throughout Euripides' corpus (Ringer 2016). 
Plutarch sets the stage at a very particular moment in mythical history. Odysseus is speaking with Circe in a manner that suggests that he has already saved his own crew from her magic and that we are toward the end of his first and longer stay on the island or, perhaps better, during his brief visit on his return from the Land of the Dead. The latter seems to be suggested in the text's opening statement from the hero: "I think that I've learned and remembered these things" (985D), which presumably refers to the information that Circe had sent Odysseus to learn from the dead seer Tiresias. This abrupt beginning immediately transitions into Odysseus' real interest, namely whether or not Circe has any Greeks among the menagerie of "manimals" living in her yard whom he might save. He expects, reasonably enough, that he would gain even greater renown if he were to bring home anyone who has been living in thrall as a beast under her magical spell. Circe acknowledges that there are quite a few Greeks and gives Odysseus a chance to persuade them to leave with him. To facilitate this exchange, she calls forth one pig, whom she dubs Gryllus ("the grunter"), who will speak on behalf of the others.

Odysseus makes his pitch to the pig and is immediately rebuffed. Gryllus says that he and the others live a life of plenty and would hate to become once again human, that "most wretched of all animals" (986D). Odysseus responds with the observation that Gryllus seems to have lost not only his human form but also his intelligence (dianoia). This quip looks back to a detail in the Odyssey where Homer specifies that Circe transformed the outward appearance of Odysseus' crew into pigs in every detail but they retained their human minds (noos, 10.239-40). Konstan stresses the point that Gryllus must be considered either completely porcine or (far preferable) completely human in the appearance of a pig, because ancient Greek thinking did not include a concept of an actual hybrid nature. That is to say that even hybrid creatures, such as centaurs, do not exhibit "a split within the rational function itself, which would take the form of a double identity," on the model of Dr. Jekyll and Mr. Hyde (Konstan 2010-2011, p. 373). Yet this point seems to be perfectly clear already in the Homeric scene and Plutarch's rebooting of it: neither author presents a pig but, rather, a human who is living in a boarish guise and lifestyle. ${ }^{19}$ For the purposes of this volume, this might seem to disqualify Gryllus from our discussion, yet since I am beginning from the assumption that we never hear actual animal voices in these texts, we are on much the same footing as we were with Achilles' horse and Archilochus' fox: we are hearing a human or divine or Golden Age voice projected into an animal body. In contrast to our archaic examples, however, Plutarch makes this more explicit.

The question then remains, what can we make of this later example of a ventriloquized voice? The dialogue plays out like a defense of the ethical capacities of animals in contrast to human shortcomings, and Newmeyer is among those who find in these arguments a strong case in favor of the existence of animal rationality (Newmeyer 2017, pp. 66-67; Newmeyer 2006). Gryllus discusses the primary virtues in succession, working through courage (andreia), moderation (sôphrosunê) and prudence (phronêsis), and in each case he argues that animals fulfill these human ideals naturally and effortlessly, whereas humans require enormous amounts of effort and training even to approximate their bestial counterparts. Yet as Konstan shows, the concept of virtue within the classical and post-classical Greek philosophical vocabulary exists separately from those capacities that a being fulfills naturally, by physis (Konstan 2010-2011, pp. 375-76). ${ }^{20}$ That is to say that if an animal naturally displays what humans would call courage, then this cannot be an example of the courageous virtue, since it is not a learned or reflective behavior but is, rather, reflexive and automatic. More modern observational studies of animal behavior complicate this picture significantly in ways that leave exceptional human capacities in serious doubt, but from the perspective of Plutarch's era, it seems unlikely that Gryllus could be read as pushing a serious proposition about animal rationality, the necessary prerequisite for the idea of animal virtue. Yet this circular system of exclusion that

19 This point is picked up by Spencer, who depicts Gryllus as happy to remain a pig because of his preexisting character: "Let Grill be Grill and have his hoggish mind" (Faerie Queene, 2.12.87).

20 Pre-classical, pre-philosophical virtue (aretê) by contrast, was inborn and therefore not a matter of training but of birth. 
privileges human definitions at every turn does not necessarily exhaust the possibility of hearing an important message in this animal voice. ${ }^{21}$

If animals cannot be virtuous, there remain two possible reasons for thinking of them as beings worthy of moral consideration. One idea, raised by Plutarch in another text (On the Eating of Animals) and endorsed by various thinkers throughout the classical era (most famously by Pythagoras and most thoroughly by Porphyry, the third-century Neoplatonist) posits that animals and humans exist within the same cycle of metempsychosis. If an animal contains the soul of my dead parent, then that animal deserves serious moral consideration and should not be eaten or mistreated. ${ }^{22}$ This theme is peripheral to Gryllus' arguments, but if Plutarch was angling for a serious reconsideration of attitudes toward animals, he may have taken up different aspects of this larger project in separate texts. What may, however, be implicit in Gryllus' strategy, is the idea that without any philosophical rigor animals have developed a manner of living that is superior even to a philosophically informed human existence. ${ }^{23}$ As Newmeyer puts it, "[in Gryllus], as in De sollertia animalium [On the Intelligence of Animals], Plutarch

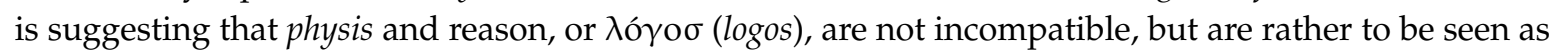
equally responsible for guiding the actions of animals"(Newmeyer 2006, p. 37). Plutarch, often quite stark in his disdain for Stoic principals, may have used Gryllus to show that even if we find the pig's philosophy to be problematic, animals exert a different but valid kind of ethical claim upon humans.

Plutarch, then, presents animals not as rational creatures (since their seemingly virtuous behaviors are the result of instinct) but, rather, as creatures who inhabit something like a Golden Age frame of existence in the here and now, in which desires are aligned with capacities and needs in such a way that virtue itself is irrelevant. Just as Adam and Eve initially had no shame at their nakedness and Greek mythology recalls an era when humans and divinities shared easy and direct interactions, Plutarch's animals have no need for virtue to achieve a good life. Virtue and philosophy, like sacrifice and prayer, are postlapsarian means for attempting to return to an idealized (perhaps hypothetical) primitive state. We need not assume that Plutarch had any real commitment to the idea that such an era actually existed for his philosophical point to carry weight. Gryllus tells us not that animals are philosophers but, rather, that animals have no need to take up philosophy (whether they could ever do so or not). As he, a human in pig form, speaks to us, we do not hear the voice of a pig-only another voice delimiting the human experience through a pathetic fallacy that maintains a human exceptionalism in response to our inability to communicate more directly with the gods we believe to be above us or the animals we assume to be beneath us. The problem with Gryllus' voice, that is, may have less to do with animals and more to do with the shortcomings of human communication that cannot adequately account for the position of Plutarch's pig. As Gryllus says, "if you do not think it appropriate to call this rationality (logos) and thought, then look for a better and more fitting word for it" (991F).

\section{The Philosopher King of the Farmyard}

Lucian of Samosata (part of the Roman province of Syria) was born about the time that Plutarch died and he himself probably expired near the beginning of the third century, though we know extremely little about his life. Like Plutarch, Lucian left us a large body of work, but his satirical and playful style contrasts sharply with that of his predecessor. ${ }^{24}$ This difference can be seen clearly in

21 This idea is paralleled in the work of Levinas, for whom a dog named Bobby played an important role in helping him develop his theory of ethics emerging from the reciprocal obligations implicit in looking into the face of another. Yet even though Bobby spurred Levinas in this direction, the philosopher never granted an important ethical subjectivity to non-human animals (Plant 2011).

22 On Plutarch and vegetarianism, see (Newmeyer 2006, pp. 85-102) and (Newmeyer 1995).

23 Such a position is associated with the opinions of Diogenes the Cynic. Plutarch's contemporary Dio Chrysostom makes this particularly clear (Oration 6.13-33 and 10.16). (Sorabji 1993, p. 161) likens this possibility to Greek narratives about noble barbarians, such as Anacharsis the Scythian.

24 The best overarching studies of Lucian's corpus are (Bompaire 1958; Branham 1989; Ní Mheallaigh 2014). 
Lucian's Cock (alternately titled The Dream, though this can cause confusion since he has another text by that name), which may respond directly to Plutarch's Gryllus. ${ }^{25}$ If Lucian did not intentionally model Cock on Gryllus, then they at least share the same basic narrative ploy. Whereas the earlier work began with Odysseus setting up an interview with one of Circe's surprisingly opinionated pigs, Lucian's Cock opens with a bleary-eyed cobbler hollering at his early-crowing rooster, who turns out to have been Pythagoras in a former life. Both texts thus orient themselves in terms of early Greek lore, both feature a human discoursing with a speaking farm animal who used to be human, and in both cases the animal comes off much better in the exchange. Yet Lucian's reworking of the human-animal conceit serves a more deconstructive purpose in questioning the pristine and primitive authority that animates most ancient examples of speaking animals.

The text begins with Micyllus the cobbler cursing his rooster for awakening him so early, since he was in the midst of an amazing dream that he was as rich as Croesus. When the rooster responds in human voice, it takes the cobbler several minutes to get his head around what is going on. There ensues a discussion about the rooster's experiences living in various human and bestial guises and then a demonstration of the vanity of human wealth. The latter point accords well with Harmon's comment that this is a "Cynic sermon in praise of poverty" (Harmon 1915, p. 171), and to some extent this is surely correct. Yet we can hear a complementary theme about the Golden Age as we pay attention to the rooster's blending of animal and philosophical voices.

As the rooster speaks, Micyllus reacts with shock and terror (2, Harmon):

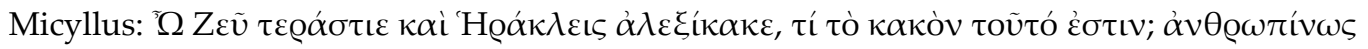

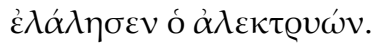

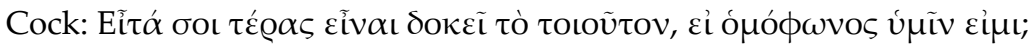

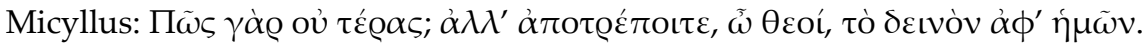

Micyllus: O Zeus of Portents (terastios) and Hercules the Averter! What evil is this?

The rooster speaks like a human!?

Cock: Why do you think it's a portent (teras) if I am homophonous to you?

Micyllus: How could it not be a portent (teras)? Please, o gods, avert this disaster from us!

The word teras (and the cognate adjective terastios) refers most directly to any sort of monster, but by this era encompasses anything marvelous that confounds expectations or, in a grander sense, the natural order. The latter seems to be appropriate in this case, and I have elsewhere analyzed a similar discussion in the picaresque Life of Aesop about the applicability of the word teras to the situation in which Aesop, born a mute slave, begins to speak (Hawkins 2016, pp. 261-63). In both texts, the possibility that the acquisition of speech might be a teras prompts reflection on the boundaries of personhood. If language (or at least complex grammatical language) is a unique attribute of humans, and if human society is organized in terms of a hierarchy of language mastery, then speaking animals and mute slaves who become loquacious similarly call attention to the principles around which the cosmos has been organized (whether in terms of a progressive transgression or a conservative statement of normative boundaries). The cock next chides Micyllus for not knowing his Homer well enough and points to the passage discussed above in which Xanthus, Achilles' horse, does not just speak but utters prophesies in hexameters. ${ }^{26}$ The combined effect of the cobbler's reference to a teras and the evocation of an old tale in which a horse speaks with divine authority reiterates the impression that the voice of the rooster signals a supernatural intervention into the normal cosmic order.

Yet that order soon begins to fray as Micyllus responds by recalling a story of metamorphosis (3). Once upon a time, a man named Alectryon ("Cock") became friends with Ares and ended up working

25 A point advanced by (Wälchi 2003, pp. 230-37). The best study of this text remains that of (Helm 1906, pp. 322-36).

26 Aelian (2nd-3rd c. CE), who wrote the largest compendium of animal lore from antiquity, includes Xanthus as one of the few examples of talking animals. He excuses Homer on the grounds of poetic license, but in the same passage chastises the backwards Egyptians for believing in the reality of a talking (and two-headed!) lamb (On the Nature of Animals, 12.3). 
as the god's lookout whenever he and Aphrodite had a fling behind Hephaestus' back. On one such occasion, Alectryon fell asleep at his post, the lovers were caught, and Ares turned his friend into an alectryon as punishment. The narrative pattern of a human becoming an animal while retaining certain traits (the rooster is still the lookout who sounds the alarm but now never oversleeps) is familiar enough, but in this case we see that the cosmic order of the gods is predicated on nothing more than soap-opera drama of lust and retribution. The cock folds himself into that divine plan when he reports that he had entered the cycle of mortal existence long ago as a punishment by Apollo for an unspecified crime (16). As he recounts his existential journey from disembodied spirit to Euphorbus (who helped Hector kill Patroclus at Troy) to Pythagoras to Aspasia (the concubine and advisor to Pericles) to Crates the Cynic and, after many intervening steps, to Mycillus' rooster, the cock does away with a host of other pretensions too. Ajax was not so impressive, Helen's beauty had faded long before the Trojan War, and Patroclus was merely an average warrior (17). Of more immediate interest to Micyllus, the famous Pythagorean prohibition against eating beans was nothing more than a publicity stunt (18). By this time, the game is up for Micyllus, who begins to laugh at the stupidity of all those who had believed the philosopher's hokum (18-19). ${ }^{27}$

Lucian's text concludes with the philosophical truism that a simple life is superior to the greed and anxieties of the rich. But that message must be evaluated in terms of the speaker. The Pythagorean cock has shown himself to be nothing more than a huckster until he finally learned through experience (rather than theory) to value an unprepossessing lifestyle. Pythagoreanism is no more believable than a talking rooster, and whatever Micyllus learns through their conversation is the product of basic but careful observation of human society. Furthermore, the gods are no nobler than the shameless philosopher or the greedy cobbler, and so the animal voice that seems to derive from a Golden Age is just the rationalizing trick of a satirist eager to debunk the lies and fictions that distract us from paying better attention to the pragmatic realities of life. ${ }^{28}$ Whereas Plutarch had used an animal voice to test the boundaries of anthropocentric philosophy, Lucian uses the same narrative pattern to call into question earlier Greek tradition at points where it admitted tales of superhuman or supernatural experience. The satirical humor of Lucian's attack on that tradition also comes to subsume his own text and its bestial narrator. His absurdist approach scours away the nonsense, leaving a realist foundation for human culture. Do away with that fantasy and rid the world of charlatans like Pythagoras. Realize that virtue is to be framed in terms of the world as we know it. Animals don't talk, metempsychosis is silly, and the gods are as corrupt as we are!

\section{Conclusions}

I have argued that many speaking animals in Greek literature emerge from a utopian system of thinking that idealizes a pristine Golden Age past in contrast to a degraded present, and I conclude by pushing this idea in three ways. First, an ancient skolion or drinking song taps into the same anxiety about communication but without any historical model. The song, preserved by Athenaeus, includes these lines: "If only we could see what sort of person each is, split open his chest and examine his mind (noos), then close him back up and know with an undeceiving mind (phrên) that he's your friend" (15.694d-e) $)^{29}$ The sentiment attests to the frustration that results from expecting communication-whether among humans or between humans and non-humans-to be free from deception or misunderstanding. Most of the examples above deal with a similar issue by positing a lost world that can be accessed through special means (much like cutting open your friend's chest

27 Lucian takes aim at Pythagoras on various occasions. The supernatural tales about him-from his many reincarnations to the legend that his thigh was made of gold-made him an easy target for the satirist's pen. For more on Lucian's engagement with Pythaboras, see (Marcovich 1988, pp. 174-77).

28 This is part of a Lucianic pattern of destabilizing canonical figures that Andrade presents in terms of an ethnic interchange between Greece and Syria (Andrade 2013, pp. 269-70).

29 Euripides has characters express this same idea at Electra 367-90, Hippolytus 925-27, and Medea 516-19. 
in hopes of truly knowing him). This skolion achieves a similar effect to those speaking animals but without drawing upon contrasting time frames or emphasizing the role of language (though the failure of human language is implicit in the skolion's message).

Secondly, the speaking animals need not have been animals at all, since Greek literature knows various speaking plants and, more rarely, inanimate objects that can serve the same narrative function. An apt example can be heard from the speaking prow of the Argo (Apollonius, Argonautica 1.526-27), Jason's ship on his quest to find the Golden Fleece. Athena outfitted the ship with this timber, which came from the sacred whispering oak of Zeus's oracular shrine at Dodona. Plutarch knows a legend that the sanctuary at Dodona had been established by Deucalion and Pyrrha, the only survivors of the Greek flood narrative (Life of Pyrrhus, 1). Dodona thus has a close connection with the antediluvian past, and the oracle continues to provide access to the divine world which has been lost in the flood. Beyond this, sailing is often presented as the technology that marks the end of the Golden Age, and the Argo is regularly depicted as the first ship ever to sail the seas ((Jackson 1997); (Romm 1996, pp. 129-30). On this tradition, then, the cutting of timber to build the first ship, which renders the sea means of connecting rather than separating people, stands for the ambivalent legacy of technology, and the speaking prow of the Argo serves much the same function as Achilles' talking horse. Animals may provide the most obvious and common medium through which Greek writers ventriloquized Golden Age voices, and the Greek imaginary included a complex set of associations that made particular animals apt choices at particular moments, but other options were available.

Finally, whereas I have presented the evidence for speaking animals mostly in synchronic terms, I end with a comment about the impact of historical change. Homer, Hesiod and Archilochus all composed in a world that did not yet know much about writing or rational philosophy. Plutarch and Lucian, by contrast, worked in the highly literate and cosmopolitan stability of the Roman Empire. Obviously a host of factors shape the cultural developments between the early and later boundaries of the classical world, yet one in particular seems relevant to this topic. Whereas our earliest Greek sources depict divine forces behind everything from diseases to weather, early classical thinkers (especially the so-called pre-Socratic philosophers and Hippocratic medical writers) proposed new theories of causation that emphasized natural processes over divine interventions (Holms 2010). If the gods bring plague (Iliad 1) and storms (Odyssey 5), then animal bodies can serve as conduits for communications from the divine realm, such that a horse or the prow of a ship can suddenly become loquacious. As natural sciences began to challenge the idea of divine causation, animals increasingly came to be understood through the observation and systemization we find in Aristotle, who, for example, drew a distinction between animal voice (phonê) and language (logos, Politics 1253a). ${ }^{30}$ Although this suggestion requires further analysis, it is reasonable to suspect that Plutarch and Lucian present human voices in animal bodies (in contrast to the speaking animals in Homer, Hesiod and Archilochus), because they lived in an era when updated perspectives on authoritative traditions put a new spin on the idea that animals might speak with a voice from the Golden Age. Plutarch elsewhere engaged with naturalistic examples of actual animal communication, especially among birds, but although these cases are critical to debates about the rational capacities of animals, they are wholly different from the idea of a talking pig (On the Cleverness of Animals, 972f-973e). Thus, Circe's animals and a reincarnated Pythagoras speak in more overtly human ways. The gods no longer choose to speak through animal bodies. Instead, authors use animals who speak as humans as literary stylizations to advance new and varied humanistic ideas.

Conflicts of Interest: The author declares no conflict of interest, though he does occasionally talk to animals.

30 (Ax 1978, 1986) study these and related Aristotelian terms in detail. 


\section{References}

Acosta-Hughes, Benjamin. 2002. Polyeideia. Berkeley: University of California Press.

Andrade, Nathaniel J. 2013. Syrian Identity in the Greco-Roman World. Cambridge: Cambridge University Press.

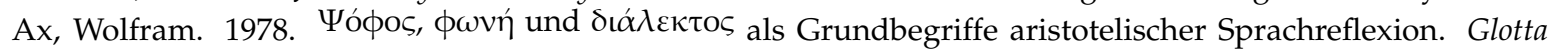
56: 245-71.

Ax, Wolfram. 1986. Laut, Stimme und Sprache. Studien zu drei Grundbegriffen der Antiken Sprachtheorie. Göttingen: Vandenhoeck \& Ruprecht.

Bompaire, Jaques. 1958. Lucien Écrivain: Imitation et Création. Paris: E. de Boccard.

Branham, R. Bracht. 1989. Unruly Eloquence: Lucian and the Comedy of Traditions. Cambridge: Harvard University Press.

Da Cunha Corrêa, Paula. 2007. A Human Fable and the Justice of Beasts. In Hesperos: Studies in Ancient Greek Poetry Presented to M. L. West on his Seventieth Birthday. Edited by Patrick J. Finglass, Christopher Collard and Nicholas J. Richardson. Oxford: Oxford University Press, pp. 101-17.

Da Cunha Corrêa, Paula. 2010. Bestiário Arcaico: Fábulas E Imagens De Animais Na Poesia De Arquiloco. São Paolo: Unicamp.

Margo DeMello, ed. 2013. Speaking for Animals: Animal Autobiographical Writing. New York: Routledge.

Diamond, Jared M. 1992. The Third Chimpanzee: The Evolution and Future of the Human Animal. New York: Harper Collins.

Edwards, Mark W. 1991. The Iliad: A Commentary, Volume V: Books 17-20. Cambridge: Cambridge University Press.

Fögen, Thorsten. 2003. Animal Communication. In The Oxford Handbook of Animals in Classical Thought and Life. Edited by Gordon Lindsay Campbell. Oxford: Oxford University Press, pp. 216-33.

Fögen, Thorsten. 2007. Antike Zeugnisse zu Kommunikationsformen von Tieren. Antike und Abendland 53: 39-75.

Franco, Cristiana. 2014. Shameless: The Canine and the Feminine in Ancient Greece. Translated by M. Fox. Berkeley: University of California Press.

Gera, Deborah Levine. 2003. Ancient Greek Ideas on Speech, Language and Civilization. Oxford: Oxford University Press. Gregory, Justina. 1999. Euripides, Hecuba: Introduction, Text, and Commentary. Atlanta: Scholars Press.

Harmon, Austin M. 1915. Lucian. Cambridge: Harvard University Press, vol. 2.

Hawkins, Tom. 2008. Out-foxing the Wolf-walker: Lycambes as performative rival to Archilochus. Classical Antiquity 27: 93-114. [CrossRef]

Hawkins, Tom. 2016. Monstrum in Fronte, Monstrum in Animo?: Sublate disgust and pharmakos logic in the Aesopic vitae. In The Ancient Emotion of Disgust. Edited by Donald Lateiner and Dimos Spatharas. Oxford: Oxford University Press, pp. 253-66.

Heath, John. 2005. The Talking Greeks: Speech, Animals and the Other in Homer, Aeschylus, and Plato. Cambridge: Cambridge University Press.

Helm, Rudolph. 1906. Lucian und Menipp. Leipzig and Berlin: B. G. Teubner.

Herman, David. 2016. Animal Autobiography; or, Narration beyond the Human. Humanities. October. Available online: http:/ / www.mdpi.com:8080/2076--0787/5/4/82 (accessed on 15 January 2017). [CrossRef]

Holms, Brooke. 2010. The Symptom and the Subject: The Emergence of the Physical Body in Ancient Greece. Princeton: Princeton University Press.

Horky, Phillip. 2017. The spectrum of animal rationality in Plutarch. Apeiron 50: 103-33. [CrossRef]

Irwin, Elizabeth. 1998. Biography, Fiction and the Archilochean ainos. Journal of Hellenic Studies 188: 177-83. [CrossRef]

Jackson, Steven. 1997. Argo: The First Ship? Rheinisches Museum für Philologie, Neue Folge 140: 249-57.

Johnston, Sarah Iles. 1992. Xanthus, Hera and the Erinyes (Il. 19. 400-18). Transactions of the American Philological Association 122: 85-98. [CrossRef]

Karban, Richard. 2015. Plant Sensing and Communication. Chicago: University of Chicago Press.

Konstan, David. 2010-2011. A Pig Convicts itself of Unreason: The Implicit Argument of Plutarch's Gryllus. Hyperboreus 16-17: 371-85.

Kovacs, David. 1987. The Heroic Muse: Studies in the Hippolytus and Hecuba of Euripides. Baltimore: Johns Hopkins University Press.

Lavigne, Donald. 2016. Archilochus and Homer in the Rhapsodic Context. In Iambus and Elegy: New Approaches. Edited by Laura Swift and Chris Carey. Oxford: Oxford University Press, pp. 74-100.

Marcovich, Miroslav. 1988. Studies in Greco-Roman Religion and Gnosticism. Leiden: E. J. Brill. 
McDonell, Jennifer. 2014. Literary Studies, the Animal Turn, and the Academy. Social Alternatives 32: 6-14.

Mossman, Judith. 1995. Wild Justice: A Study of Euripides' Hecuba. Oxford: Oxford University Press.

Muellner, Leonard. 1996. The Anger of Achilles: Menis in Greek epic. Ithaca: Cornell University Press.

Newmeyer, Stephen T. 1995. Plutarch on the Moral Grounds for Vegetarianism. Classical Outlook 72: 41-43.

Newmeyer, Stephen T. 2006. Animals, Rights and Reason in Plutarch and Modern Ethics. New York: Routledge.

Newmeyer, Stephen T. 2017. The Animal and the Human in Ancient and Modern Thought: The 'Man Alone of Animals' Concept. New York and London: Routledge.

Ní Mheallaigh, Karen. 2014. Reading Fiction with Lucian: Fakes, Freaks and Hyperreality. Cambridge: Cambridge University Press.

Payne, Mark. 2010. The Animal Part. Chicago: Chicago University Press.

Perry, Ben Edward. 1952. Aesopica. Urbana: University of Illinois Press.

Plant, Bob. 2011. Welcoming Dogs: Levinas and the 'animal question'. Philosophy and Social Criticism 37: 49-71. [CrossRef]

Emily Plec, ed. 2013. Persectives on Human-Animal Communication: Internatural Communication. New York: Routledge. Radick, Gregory. 2007. The Simian Tongue: The Long Debate about Animal Language. Chicago: University of Chicago Press.

Ringer, Mark. 2016. Euripides and the Boundaries of the Human. London: Lexington Books.

Romm, James. 1996. Dog Heads and Noble Savages: Cynicism before the Cynics? In The Cynics: The Cynic Movement in Antiquity and Its Legacy. Edited by R. Bracht Branham and Marie-Odile Goulet-Cazé. Berkeley: University of California Press, pp. 121-35.

Scodel, Ruth. 1982. The Achaean Wall and the Myth of Destruction. Harvard Studies in Classical Philology 86: 35-50. [CrossRef]

Sorabji, Richard. 1993. Animal Minds and Human Morals: The origins of the Western Debate. Ithaca: Cornell University Press.

Spittler, Janet E. 2008. Animals in the Apocryphal Acts of the Apostles: The Wild Kingdom of Early Christian Literature. Tübingen: Mohr Siebeck.

Steiner, Deborah. 2010. Framing the Fox: Callimachus' second Iamb and its predecessors. Journal of Hellenic Studies 130: 97-107. [CrossRef]

Vidal-Naquet, Pierre. 1998. The Black Hunter: Forms of thought and Forms of Society in the Greek World. Translated by Andrew Szegedy-Maszak. Baltimore: Johns Hopkins University Press.

Wälchi, Philipp. 2003. Studien zu den Literarischen Beziehungen Zwischen Plutarch und Lukian. Leipzig: Walter de Gruyter. Wolfe, Tom. 2016. The Kingdom of Speech. New York: Little, Brown and Company. 